\title{
Recovery of Iron Bearing Minerals from Beneficiation Plant 2 Thickner Underflow of JSW Steel Limited
}

\author{
Tekkalakote Umadevi, Amit Pratap Singh, Kumar Abhishek, Basavareddy Suresh, Rameshwar Sah \\ R\&D and SS, JSW Steel Limited, Bellary, India \\ Email: uma.devi@jsw.in
}

Received November 2, 2012; revised December 12, 2012; accepted December 22, 2012

\begin{abstract}
To identify and establish beneficiation techniques for slime, a comprehensive research work was carried out on beneficiation plant 2 thickener underflow (Tailing). Iron ore slimes $(-45$ micron $\sim 80.0 \%)$ generated at beneficiation plant 2 assaying $46.7 \% \mathrm{Fe}, 10.82 \% \mathrm{SiO}_{2}$, and $4.58 \% \mathrm{Al}_{2} \mathrm{O}_{3}$ have been subjected to various beneficiation studies like cyclone, wet high intensity magnetic separator and flotation to recover the iron bearing minerals. The effects of different operating parameters have been studied to get a product suitable for pellet making. Detailed beneficiation studies indicate that it is possible to obtain a product containing $61.8 \%$ to $66.6 \% \mathrm{Fe}, 1.80 \%$ to $3.35 \% \mathrm{SiO}_{2}$, and $1.65 \%$ to $2.40 \% \mathrm{Al}_{2} \mathrm{O}_{3}$ with $8.0 \%$ to $22.3 \%$ weight recovery by adopting de-sliming followed by magnetic separation. Within this product grade range the pellet grade fines (JSW norms-minimum $63.0 \% \mathrm{Fe}$ ) consist of $63.0 \% \mathrm{Fe}, 2.97 \% \mathrm{SiO}_{2}$ and $2.48 \% \mathrm{Al}_{2} \mathrm{O}_{3}$ with $16.9 \%$ weight recovery and $56.9 \%$ Fe recovery at 0.5 Tesla magnetic field intensity, pulsation rate $230 \mathrm{rpm}$ and $2 \mathrm{~min}$ residence time.
\end{abstract}

Keywords: Beneficiation Plant; Tails/Slimes; Gavity Separation; Magnetic Separation, Flotation

\section{Introduction}

In JSW Steel Limited, iron ore is being beneficiated to meet the quality requirement for iron making units. JSW Steel Limited is 10 Mtpa integrated steel plant and requires nearly $25 \mathrm{Mtpa}$ iron ore to produce a ton of steel. In India, Bellary-Hospet region is endowed with large reserves of good quality of iron ore. The iron ore of this region is although rich in iron content but suffers from two disadvantages. One is high alumina content in the iron ore and second is softness of the ore which generates huge quantity of fines and slimes during mining and beneficiation. JSW Steel limited operates $3.0 \mathrm{mtpa}$ and 13.0 Mtpa beneficiation plant 1 and beneficiation plant 2 to beneficiate medium grade and low grade iron ore fines in the range of $58 \%$ to $61 \% \mathrm{Fe}$ and $55 \%$ to $60 \% \mathrm{Fe}$ respectively. Beneficiation plant 2 circuits consist of crusher, scrubber, two stage classifier, spiral, and hydrocyclone and wet high intensity magnetic separator. During the beneficiation of low grade iron ore nearly $25 \%$ to $30 \%$ (3.25 to $3.90 \mathrm{Mtpa}$ ) of the material is disposed into the tailing ponds as slimes. The discarded slimes contain approximately $46 \%$ to $53 \% \mathrm{Fe}, 7 \%$ to $8 \%$ alumina and $9 \%$ to $10 \%$ silica. These slimes contain $70 \%-80 \%$ minus 25 microns material, which is unique as compared to slimes elsewhere. In order to recover additional values from these slimes, detailed beneficiation studies have been carried out on thickener U/F (Tailing) sample of beneficiation plant 2 .

The beneficiation of iron ore slime produced from washing plants and tailing ponds of Kiriburu mines was studies [1] using wet high intensity magnetic separator followed by classification in a hydrocyclone. They showed that a concentrate assaying $63 \% \mathrm{Fe}$ and $3.3 \%$ alumina could be produced with an overall iron recovery of $56 \%$. Similarly Das et al. [2] studied iron ore slimes from Barusa, Bolani and Kiriburu using classification by hydrocyclone followed by wet high intensity magnetic separation. Their results indicated that a concentrate assaying $60 \%$ to $65 \% \mathrm{Fe}$ with $60 \%$ to $80 \%$ recovery can be obtained. Multigravity separator is a useful technique for treating iron ore slime and particularly effective in reducing alumina content [3]. However, it is not very successful commercially due to its low capacity [4]. Studies have been carried out on two slime samples from Boloani iron ore washing plant revealed the possibility of recovering both iron as well as water effectively. The separation in hydrocyclone gives the products having $64 \%$ to $65 \% \mathrm{Fe}$ could be obtained with less than $2.0 \% \mathrm{SiO}_{2}$ and $\mathrm{Al}_{2} \mathrm{O}_{3}$ from feed having $59 \%$ to $60 \% \mathrm{Fe}, 4.0 \% \mathrm{SiO}_{2}$ and $4.80 \% \mathrm{Al}_{2} \mathrm{O}_{3}[5]$.

The beneficiation of JSW slimes containing significant amount of $\mathrm{Fe}$ along with $\mathrm{SiO}_{2}$ and $\mathrm{Al}_{2} \mathrm{O}_{3}$ is quite difficult. It is also difficult to know the characteristics of these slimes due to finer size below 25 to 50 micron size. 
Hence, in the present case magnetic separation and flotation process were adopted on hydrocyclone product to study the slimes of the size 25 to 50 micron size.

\section{Experimental}

The sample was collected from BP2 plant thickener and transported to R\&D laboratory. The average particle size of the sample was found to be 35 micron. The sample was thoroughly mixed and prepared the representative sample for different investigations. Various physicochemical, mineralogical and beneficiation studies were carried out to recover iron bearing minerals from slimes as pellet feed. Size wise analysis was carried out on slime sample to know the particle distribution and elemental distribution at different sizes using 150 to 25 micron size screen and cyclosizer.

Since the slime samples are very fine, optical microscopic study is not very convenient. However, with some care polished sections were studies by cold mounting under optical microscope. Size analysis of the sample at various beneficiation steps were carried out using Hellos particle size analyser.

The laboratory batch scale beneficiation studies were carried out using hydrocyclone, wet high intensity magnetic separator and flotation.

Bench scale hydrocyclone studies were carried out on received sample using $75 \mathrm{~mm}$ hydrocyclone. Total 3 numbers of experiments were carried out by varying the spigot diameter 5,8 and $10 \mathrm{~mm}$. The other operating parameters like vortex finder diameter $25 \mathrm{~mm}$, cyclone operating pressure 30 Psi, percentage of solids $12 \%$ were kept constant for all experiments. The products obtained from the de-sliming cyclone separation studies were collected, dried, taken weight and sent for chemical analysis.

Bench scale magnetic separation studies were carried out with a laboratory model Slon wet high intensity (WHIMS) magnetic separator. In the bench scale separator supplied by Slon magnetic separator, China, a $1 \mathrm{~mm}$ grid plate was selected based on the particle size of the material. The experiments were carried by varying magnetic field intensity, residence time and pulsation rate.

A Denver D-12 sub-aeration flotation cell of 1 liter capacity was used for laboratory batch scale flotation studies. The sample was conditioned at $20 \%$ solids with the desired amounts of reagents for a predetermined time. The starch, amine (Sokem 503C and 523C) and methyl isobutyl carbinol (MIBC) was used as the depressant, collector and frother respectively. Diluted sodium hydroxide of analytical grade was used as $\mathrm{pH}$ regulator. The concentrates and tailings of the flotation process were collected separately, dried, weighed, and analysed to access product quality and recovery.
Total 11 numbers of experiments were carried out by varying the slurry $\mathrm{pH}$ from 9 to 10 , collector dosage from 0.4 to $1.0 \mathrm{~kg} / \mathrm{t}$ with the interval of $0.2 \mathrm{~kg} / \mathrm{t}$ and the depressant dosage was varied from 0.8 to $1.0 \mathrm{~kg} / \mathrm{t}$. During flotation studies $20 \%$ solids, impeller rpm 1200 and frother dosage $0.02 \mathrm{~kg} / \mathrm{t}$, conditioning time $5 \mathrm{~min}$ and froth collection time 4 min were kept constant for all experiments. The products obtained from the each flotation studies were collected, dried, taken weight and sent for chemical analysis.

\section{Results and Discussion}

\subsection{Characterization Studies of Slimes}

The complete chemical analysis of the slime sample is shown in Table 1. The sample contains $46.7 \% \mathrm{Fe}$, $10.82 \% \mathrm{SiO}_{2}$, and $7.95 \% \mathrm{Al}_{2} \mathrm{O}_{3}$. The iron oxide content in the sample is $66.8 \%$. From the analysis it was observed that silica and alumina is the major gangue minerals present in the sample. The -10 micron size consists of $33.0 \% \mathrm{Fe}$. The size and chemical analysis of the individual fractions are shown in Figure 1. From the chemical analysis of the various size fractions, it is observed that Fe content at various fractions decreased with decrease in size. From the size analysis it was realized that the separation of gangue minerals from iron in the bulk ore by any classification technique, which had been used to treat typical Indian iron ore slimes where gangue materials preferentially accumulated in finer sizes, would be effective. Figure 2 shows the cumulative passing size of the bulk sample. Cumulative $80 \%$ passing size of the sample is $35 \mu \mathrm{m}$ size.

\subsection{Mineralogical Studies}

Mineralogical characterization studies were carried out on polished sections using optical microscope. Hematite,

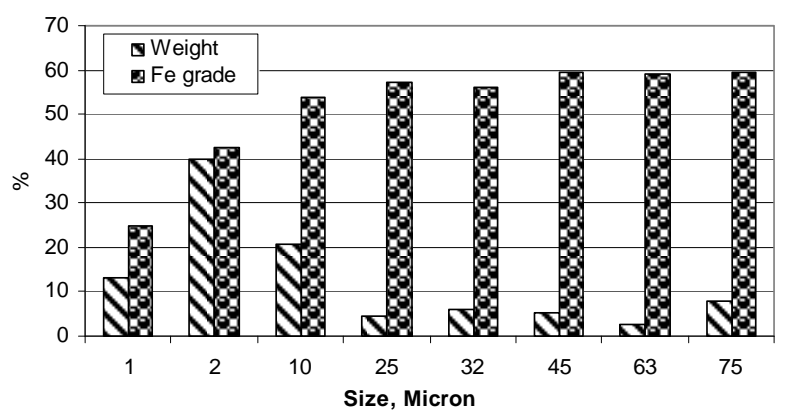

Figure 1. Size and chemical analysis of the fractions.

Table 1. Chemical analysis of the bulk sample.

\begin{tabular}{cccccccc}
\hline \multicolumn{7}{c}{$\mathrm{wt}^{\%} \%$} \\
\hline $\mathrm{Fe}$ & $\mathrm{Fe}_{2} \mathrm{O}_{3}$ & $\mathrm{SiO}_{2}$ & $\mathrm{Al}_{2} \mathrm{O}_{3}$ & $\mathrm{CaO}$ & $\mathrm{MgO}$ & $\mathrm{MnO}$ & LOI \\
\hline 46.7 & 66.8 & 10.82 & 7.95 & 0.177 & 0.019 & 2.75 & 8.72 \\
\hline
\end{tabular}


goethite and martite are the major iron bearing minerals and quartz and koalinite are the major gangue minerals. Magnetite is oxidized to martite. Goethite consists of hematite and martite inclusions. Figure 3 shows the phase analysis of the bulk sample. The sample consists of $71.0 \%$ iron bearing minerals and $29.0 \%$ gangue bearing minerals in which goethite contribute $40 \%$ by area.

\subsection{Beneficiation Studies}

The key to successful utilization of slimes (beneficiation plant 2 tails) is to develop a beneficiation strategy, which is economical and consistent with its mineralogy and fineness of the particles. It has been found from the detail chemical and mineralogical studies that iron content in the finer size below 10 micron size is very low. Also, silica and alumina content increases with decrease in particle size. It is therefore apparent that the preliminary concentration by hydrocyclone could be achieved as silica and alumina particles are distributed at finer size. So it is decided to explore the hydrocyclone studies followed by magnetic separation and flotation studies to achieve pellet grade concentrate.

\subsubsection{Separation by Hydrocyclone}

The results of the hydrocyclone studies are shown in Table 2. Figure 4 shows the influence of spigot diameter on

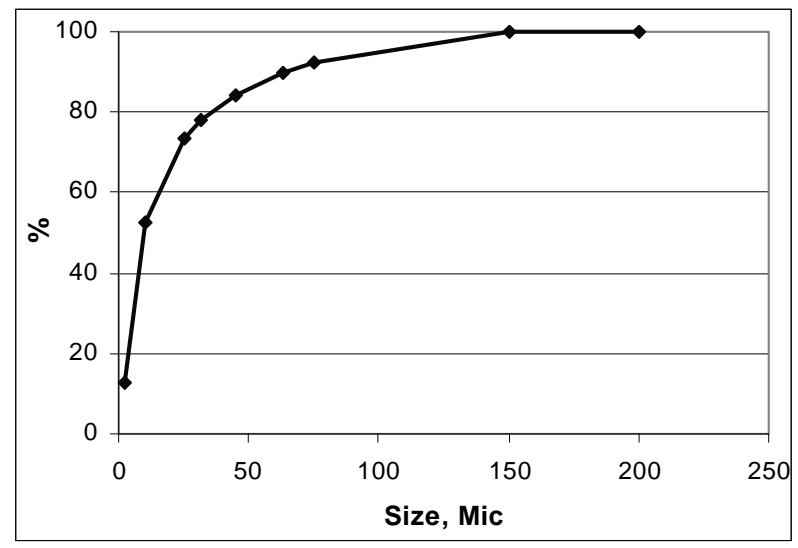

Figure 2. Cumulative passing size of the bulk sample.

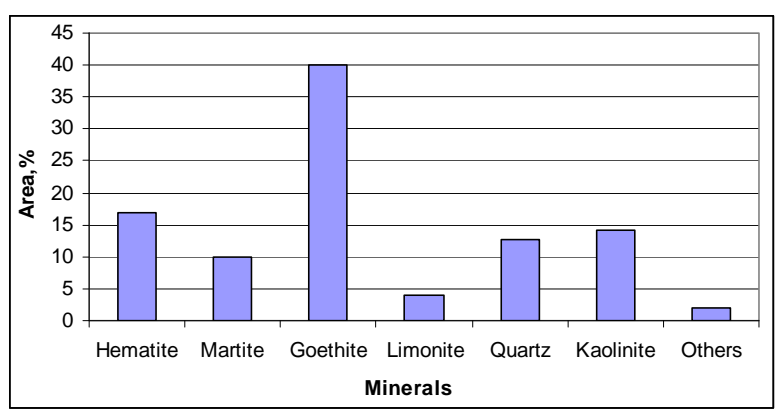

Figure 3. Phase analysis of the bulk sample.

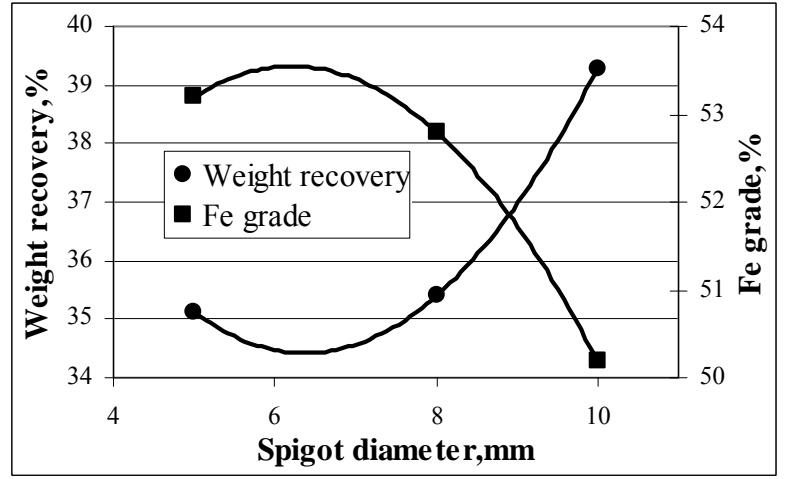

Figure 4. Influence of cyclone spigot diameter on product weight recovery and $F e$ grade.

Table 2. Results of hydrocyclone studies.

\begin{tabular}{cccccc}
\hline Spigot dia, $\mathrm{mm}$ Products & Yield & $\mathrm{Fe}$ & $\mathrm{SiO}_{2}$ & $\mathrm{Al}_{2} \mathrm{O}_{3}$ \\
\hline \multicolumn{5}{c}{$\mathrm{wt}^{2} \%$} \\
\hline \multirow{2}{*}{5} & $\mathrm{~F} / \mathrm{F}$ & 35.1 & 53.2 & 6.72 & 4.58 \\
& $\mathrm{O} / \mathrm{F}$ & 64.9 & 43.2 & 13.04 & 9.77 \\
\multirow{2}{*}{8} & $\mathrm{U} / \mathrm{F}$ & 35.4 & 52.9 & 6.85 & 4.68 \\
& $\mathrm{O} / \mathrm{F}$ & 64.6 & 43.3 & 13.00 & 9.74 \\
\multirow{2}{*}{10} & $\mathrm{U} / \mathrm{F}$ & 39.3 & 50.2 & 7.01 & 5.22 \\
& $\mathrm{O} / \mathrm{F}$ & 60.7 & 44.4 & 13.28 & 9.72 \\
\hline
\end{tabular}

product yield and Fe grade. With increase in spigot diameter from 5 to $10 \mathrm{~mm}$ concentrate yield increased from $35.12 \%$ to $39.28 \%$ and $\mathrm{Fe}$ grade decreased from $53.2 \%$ to $50.2 \%$. For further beneficiation studies, the hydro-cyclone underflow of $8 \mathrm{~mm}$ spigot product was considered. The results indicate that iron grade of $52.9 \% \mathrm{Fe}, 6.72 \%$ $\mathrm{SiO}_{2}$ and $4.58 \% \mathrm{Al}_{2} \mathrm{O}_{3}$ with $35.4 \%$ yield can be obtained at $8 \mathrm{~mm}$ spigot diameter. With spigot diameter $5 \mathrm{~mm}$ and $8 \mathrm{~mm}$ size Fe grade and recovery of the underflow product is comparable.

Figure 5 shows the d50 cut point of the de-sliming cyclone. The de-sliming cyclone d50 cut point is 12.1 micron.

\subsubsection{Separation by Wet High Intensity Magnetic Separator (WHIMS)}

Magnetic separation studies were carried out using SLON make batch scale SLON 100 vertical pulsating cyclic magnetic separator.

The results of WHIMS studies on slime sample of hydrocyclone underflow (8 $\mathrm{mm}$ spigot) at different magnetic field intensity $(\mathrm{T})$, slurry pulsation rate (rpm) and slurry residence time ( $\mathrm{min}$ ) are shown in Tables 3-5 respectively. In WHIMS separator the magnetic field intensity was varied from 0.15 to 0.7 Tesla. Figure 6 shows the influence of magnetic field intensity on product weight 


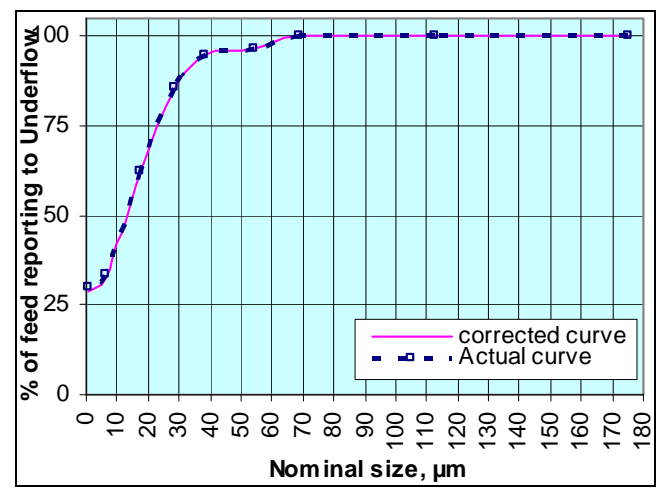

Figure 5. d50 cut point of the de-sliming cyclone.

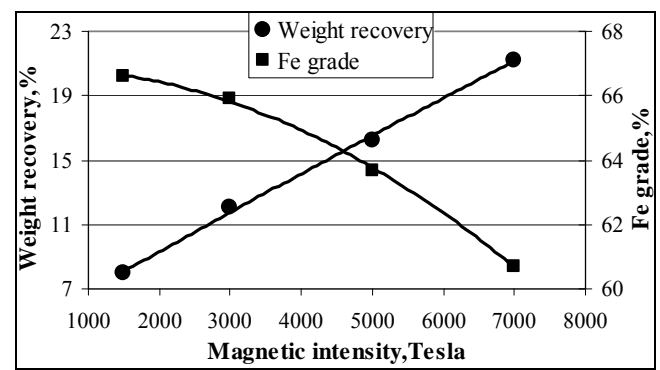

Figure 6. Influence of magnetic field intensity on product weight recovery and Fe grade.

Table 3. Results of magnetic separation studies at different magnetic field intensity with 3 min residence time and 230 rpm pulsation rate.

\begin{tabular}{cccccc}
\hline \multirow{2}{*}{$\begin{array}{c}\text { Magnetic } \\
\text { intensity/T }\end{array}$} & Products & $\mathrm{Yield}$ & $\mathrm{Fe}$ & $\mathrm{SiO}_{2}$ & $\mathrm{Al}_{2} \mathrm{O}_{3}$ \\
\cline { 3 - 6 } 0.15 & Magnetic & 22.5 & 66.6 & 1.80 & 1.65 \\
& Non-magnetic & 77.5 & 49.0 & 8.25 & 5.52 \\
\multirow{2}{*}{0.3} & Magnetic & 34.0 & 65.9 & 2.10 & 1.98 \\
& Non-magnetic & 66.0 & 46.1 & 9.15 & 6.10 \\
\multirow{2}{*}{0.5} & Magnetic & 46.0 & 63.7 & 2.80 & 2.25 \\
\multirow{2}{*}{0.7} & Non-magnetic & 54.0 & 44.0 & 10.26 & 6.65 \\
& Magnetic & 63.0 & 61.8 & 3.35 & 2.40 \\
& Non-magnetic & 37.0 & 42.1 & 11.65 & 7.80 \\
\hline
\end{tabular}

Table 4. Results of magnetic separation studies at different pulsation rate with $3 \mathrm{~min}$ residence time and $0.5 \mathrm{~T}$ magnetic field intensity.

\begin{tabular}{cccccc}
\hline \multirow{2}{*}{ Pulsation rate, } & Products & Yield & $\mathrm{Fe}$ & $\mathrm{SiO}_{2}$ & $\mathrm{Al}_{2} \mathrm{O}_{3}$ \\
\cline { 3 - 6 } & & \multicolumn{4}{c}{$\mathrm{wt} \%$} \\
\hline \multirow{2}{*}{210} & Magnetic & 49.8 & 61.7 & 3.08 & 2.38 \\
& Non-magnetic & 50.2 & 44.2 & 10.33 & 6.76 \\
\multirow{2}{*}{230} & Magnetic & 46.0 & 63.7 & 2.80 & 2.25 \\
& Non-magnetic & 54.0 & 44.0 & 10.26 & 6.65 \\
& Magnetic & 41.2 & 64.7 & 2.45 & 2.15 \\
& Non-magnetic & 58.8 & 44.7 & 9.71 & 6.28 \\
\hline
\end{tabular}

recovery and Fe grade. With increase in magnetic field intensity the weight recovery of the magnetic product increased and Fe grade decreased based on the magnetic susceptibility of the ore. At 1500 gauss magnetic field intensity, $3 \mathrm{~min}$ residence time and $230 \mathrm{rpm}$ pulsation rate achieved $66.6 \% \mathrm{Fe}, 1.80 \% \mathrm{SiO}_{2}$, and $1.65 \% \mathrm{Al}_{2} \mathrm{O}_{3}$ with $8.0 \%$ weight recovery. As per JSW Steel Limited norms, the iron ore fines grade required for pellet making is $63.0 \% \mathrm{Fe}$.

For better separation and to minimize the entrapment of gangue minerals with iron bearing minerals it is necessary to apply the strong matrix pulsation. Figure 7 shows the trapping of the minerals on the matrix at different pulsation rate. To know the influence of matrix pulsation rate on magnetic separator product yield and grade detailed studies have been carried out by varying the pulsation rate from 210 to $230 \mathrm{rpm}$.

Figure 8 shows the influence of slurry pulsation rate

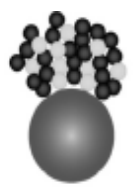

no pulsation

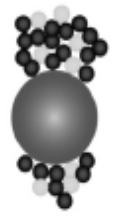

weak pulsation

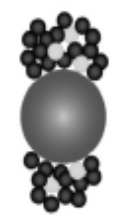

moderate pulsation strong pulsation
- Magnetic material

Non-magnetic material

Figure 7. Particle loading on pulsating matrix.

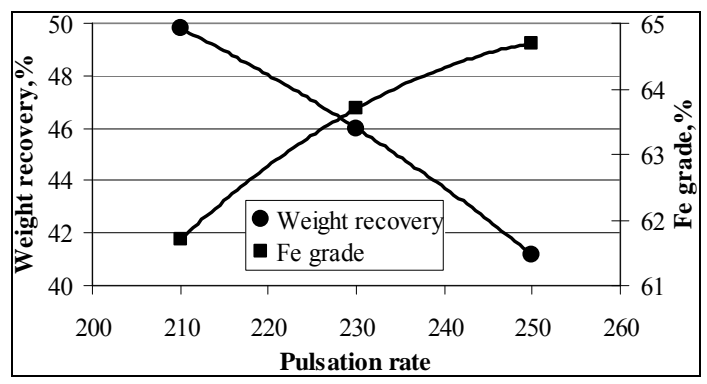

Figure 8. Influence of pulsation rate on product weight recovery and Fe grade.

Table 5. Results of magnetic separation studies at different pulsation residence time with $230 \mathrm{rpm}$ pulsation rate and 0.5 T magnetic field intensity.

\begin{tabular}{cccccc}
\hline \multirow{2}{*}{$\begin{array}{c}\text { Residence } \\
\text { time/min }\end{array}$} & Products & Yield & $\mathrm{Fe}$ & $\mathrm{SiO}_{2}$ & $\mathrm{Al}_{2} \mathrm{O}_{3}$ \\
\cline { 3 - 6 } 2 & Magnetic & 47.8 & 63.0 & 2.97 & 2.48 \\
& Non-magnetic & 52.2 & 43.7 & 10.15 & 6.50 \\
& Magnetic & 46.0 & 63.7 & 2.80 & 2.25 \\
3 & Non-magnetic & 54.0 & 44.0 & 10.26 & 6.65 \\
& Magnetic & 45.8 & 64.0 & 2.75 & 2.19 \\
4 & Non-magnetic & 54.2 & 43.5 & 10.07 & 6.60 \\
\hline
\end{tabular}


on product yield and recovery. With increase in slurry pulsation rate the magnetic yield recovery decreased and Fe grade increased. At matrix pulsation rate $250 \mathrm{rpm}$, magnetic field intensity 0.5 Tesla, and 3 min residence time achieved $64.7 \% \mathrm{Fe}, 2.45 \% \mathrm{SiO}_{2}$, and $2.15 \% \mathrm{Al}_{2} \mathrm{O}_{3}$ with $41.2 \%$ weight recovery and $50.4 \%$ iron recovery.

To separate the trapped gangue minerals with iron bearing minerals and for better separation of iron bearing minerals from gangue minerals the matrix pulsation residence time is more important. To know the influence of matrix pulsation residence time on magnetic separator product yield and grade the residence time was varied from 2 to $4 \mathrm{~min}$. Figure 9 shows the influence of pulsation residence time on magnetic separator product yield and grade. With increase in pulsation residence time the product yield decreased and Fe grade increased. From the results it was found that at residence time 3 and $4 \mathrm{~min}$ not found much difference in product yield and grade. At pulsation time $4 \mathrm{~min}$, magnetic field intensity 0.5 Tesla and pulsation rate $230 \mathrm{rpm}$ achieved $64.0 \% \mathrm{Fe}, 2.75 \%$ $\mathrm{SiO}_{2}, 2.19 \% \quad \mathrm{Al}_{2} \mathrm{O}_{3}$ with $45.8 \%$ weight recovery and $55.4 \%$ Fe recovery.

At magnetic field intensity 0.5 Tesla, pulsation rate $230 \mathrm{rpm}$, and residence time $2 \mathrm{~min}$ achieved pellet grade fines with $63.0 \% \mathrm{Fe}, 2.97 \% \mathrm{SiO}_{2}$ and $2.48 \% \mathrm{Al}_{2} \mathrm{O}_{3}$ with $16.9 \%$ weight recovery and $56.9 \%$ Fe recovery.

\subsubsection{Separation by Froth Flotation Process}

Reverse flotation studies were carried out on de-sliming cyclone underflow using amine collector (SOCEM 503C), laboratory grade starch as depressant and MIBC as frother. The results of flotation studies at different $\mathrm{pH}$ are shown in Table 6. At $\mathrm{pH} 9.5$ with Depressant dosage $0.8 \mathrm{~kg} / \mathrm{t}$, collector dosage $0.6 \mathrm{~kg} / \mathrm{t}$, frother dosage 0.02 $\mathrm{kg} / \mathrm{t}$, conditioning time $5 \mathrm{~min}$ achieved better results. For optimization of reagents dosage $\mathrm{pH} 9.5$ was considered.

Figure 10 shows the influence of collector dosage on flotation product weight recovery and Fe grade at 0.8 and $1.0 \mathrm{~kg} / \mathrm{t}$ depressant dosage. At depressant dosage $0.8 \mathrm{~kg} / \mathrm{t}$ as well as $1.0 \mathrm{~kg} / \mathrm{t}$, with increase in collector dosage the product weight recovery decreased and Fe grade increased. At optimum collector dosage $1.0 \mathrm{~kg} / \mathrm{t}$ depressant

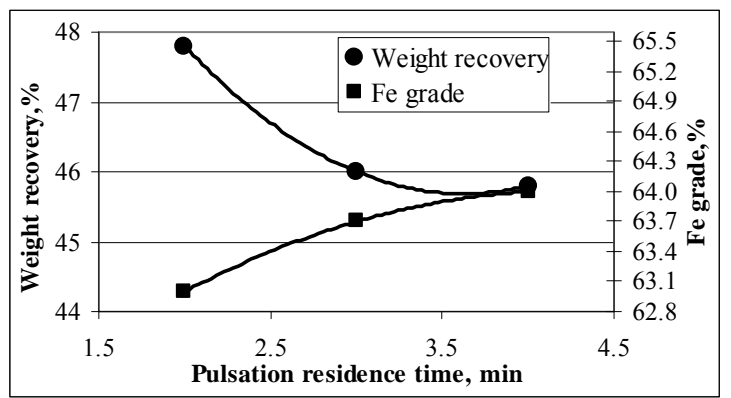

Figure 9. Influence of residential time on product weight recovery and $\mathrm{Fe}$ grade. dosage $0.8 \mathrm{~kg} / \mathrm{t}$, frother dosage $0.02 \mathrm{~kg} / \mathrm{t}$ achieved $58.90 \% \mathrm{Fe}, 3.45 \% \mathrm{SiO}_{2}$, and $2.51 \% \mathrm{Al}_{2} \mathrm{O}_{3}$ with $27.6 \%$ weight recovery.

\section{Flow Sheet Development}

Considering the cost of separation and a better grade with reasonable recovery of iron bearing minerals by adopting a magnetic separation route in comparison to floatation, a flow sheet incorporating magnetic separation (WHIMS) has been suggested. The proposed flow sheet for slime processing is shown in Figure 11. The flow sheet sug-

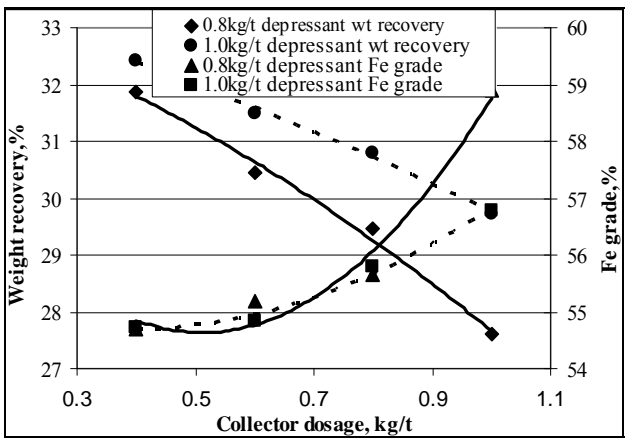

Figure 10. Influence of collector dosage on product weight recovery and Fe grade at different depressant dosage.

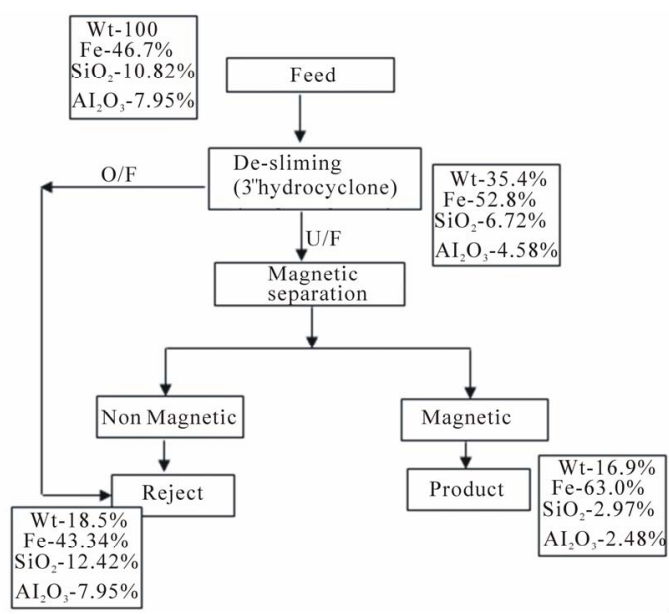

Figure 11. Flow sheet for beneficiation of slimes.

Table 6. Results of flotation studies (depressant dosage 0.8 $\mathrm{kg} / \mathrm{t}$, collector dosage $0.6 \mathrm{~kg} / \mathrm{t}$, frother dosage $0.02 \mathrm{~kg} / \mathrm{t}$, conditioning time $5 \mathrm{~min}$ ).

\begin{tabular}{|c|c|c|c|c|c|c|}
\hline \multirow{2}{*}{ Slurry pH } & \multirow{2}{*}{ Products } & Yield & $\mathrm{Fe}$ & $\mathrm{SiO}_{2}$ & $\mathrm{Al}_{2} \mathrm{O}_{3}$ & Fe recovery \\
\hline & & \multicolumn{5}{|c|}{$\mathrm{wt} \%$} \\
\hline \multirow{2}{*}{9.0} & Concentrate & 79.0 & 56.0 & 5.49 & 3.58 & 83.79 \\
\hline & Tails & 21.0 & 40.8 & 11.35 & 8.34 & \\
\hline \multirow{2}{*}{9.5} & Concentrate & 84.9 & 55.6 & 5.55 & 3.74 & 89.40 \\
\hline & Tails & 15.1 & 32.2 & 13.30 & 9.30 & \\
\hline \multirow{2}{*}{10.0} & Concentrate & 81.0 & 52.8 & 6.05 & 4.35 & 81.00 \\
\hline & Tails & 52.8 & 52.8 & 9.58 & 5.56 & \\
\hline
\end{tabular}


gest that the de-sliming of the cyclone followed by magnetic separation. The magnetic separator concentrate is considered as final product and non magnetic can be rejected as tails. Thus, from this flow sheet it is possible to obtain pellet grade product with $63.0 \% \mathrm{Fe}, 2.97 \% \mathrm{SiO}_{2}$ and $2.48 \% \mathrm{Al}_{2} \mathrm{O}_{3}$ with $16.9 \%$ weight recovery and $56.9 \%$ Fe recovery.

\section{Conclusions}

- The sample consists of $46.7 \% \mathrm{Fe}, 10.82 \% \mathrm{SiO}_{2}$ and $7.95 \% \quad \mathrm{Al}_{2} \mathrm{O}_{3}$. The major iron bearing minerals are goethite, hematite, martite and gangue bearing minerals are quartz and clay.

- The beneficiation studies using magnetic separation techniques have established the recovering of excellent grade. The results clearly indicates that it is possible to achieve product grade $61.8 \%$ to $66.6 \% \mathrm{Fe}$, $1.80 \%$ to $3.35 \% \mathrm{SiO}_{2}$, and $1.65 \%$ to $2.40 \% \mathrm{Al}_{2} \mathrm{O}_{3}$ with $8.0 \%$ to $22.3 \%$ weight recovery by adopting de-sliming followed by magnetic separation.

- At magnetic field intensity 0.5 Tesla, pulsation rate $230 \mathrm{rpm}$, and residence time $2 \mathrm{~min}$ achieved pellet grade fines with $63.0 \% \mathrm{Fe}, 2.97 \% \mathrm{SiO}_{2}$ and $2.48 \%$ $\mathrm{Al}_{2} \mathrm{O}_{3}$ with $16.9 \%$ weight recovery and $56.9 \% \mathrm{Fe}$ recovery.

- The flotation studies carried out using conventional flotation cell indicate that lower $\mathrm{Fe}$ grade product with higher recovery was achieved compared to magnetic separation process by adopting de-sliming flowed by flotation. The flotation concentrate consist of $58.90 \% \mathrm{Fe}, 3.45 \% \mathrm{SiO}_{2}$, and $2.51 \% \mathrm{Al}_{2} \mathrm{O}_{3}$ with $27.6 \%$ weight recovery.

\section{REFERENCES}

[1] N. Prasad, M. A. Ponomarev, S. K. Mukherjee, P. K. Sengupta and S. K. Gupta, "Introduction of New Technologies for Beneficiation of Indian Hematite Ores," Reduction of Looses and Increase in Their Quality," In: K. S. E. Forssberg, Ed., Proceedings of XVI International Mineral Processing Congress, Stockholm, 1998, pp. 13691380.

[2] B. Das, S. Prakash, B. K. Mohapatra, S. K. Bhaumik and K. S. Narashimhan, "Beneficiation of Iron Ore Slimes Using Hydrocyclone," Mineral and Metallurgical Processing, Vol. 9, No. 2, 1994, pp. 101-103.

[3] S. Pradeep, "Beneficiation of Indian Iron Ore Slimes," Minerals \& Metallurgical Processing, Vol. 6, No. 3, 1994, pp. 179-194.

[4] S. Roy and A. Das, "Characterization and Processing of Low Grade Iron Ore Slime from Jilling Area of India," Mineral Processing and Extractive Metallurgy Review: An International Journal, Vol. 29, 2008, pp. 213-231. doi: $10.1080 / 08827500801997886$

[5] G. V. Rao and M. I. Ansari, "Recovery of Iron Ore Superfines and Water from Slimes of Bolani Iron Ore Washing Plant," Transactions of the Indian Institute of Metals, Vol. 46, No. 2, 1993, pp. 51-55. 